\title{
ANALISA DAN PERANCANGAN ENTERPRISE ARCHITECTURE PADA FUNGSI PRODUKSI TANAMAN PANGAN DAN HORTIKULTURA DINAS TANAMAN PANGAN DAN HORTIKULTURA PROVINSI JAWA BARAT MENGGUNAKAN FRAMEWORK TOGAF ADM
}

\author{
${ }^{1}$ Tesi Irwani, ${ }^{2}$ Yuli Adam Prasetyo, ${ }^{3}$ Ridha Hanafi \\ 1,2,3 Program Studi Sistem Informasi, Fakultas Rekayasa Industri, Telkom University \\ 1'tesirwani@gmail.com, ${ }^{2}$ adam@telkomuniversity.ac.id, ${ }^{3}$ ridhanafi@gmail.com
}

\begin{abstract}
Abstrak - Teknologi informasi (TI) telah menjadi salah satu strategi utama dalam mendukung perusahaan atau instansi untuk keberlangsungan prosesproses yang ada sehingga dapat mencapai tujuannya. Begitu pula dengan instansi pemerintahan yang perlu menyelaraskan antara strategi bisnis dengan strategi TI yang sesuai dengan kebutuhan instansi. Instansi pemerintahan yang menjadi objek pada penelitian ini adalah Dinas Tanaman Pangan dan Hortikultura Provinsi Jawa Barat, yang melaksanakan urusan daerah bidang pertanian. Dalam menjalankan proses bisnisnya, instansi belum dapat mengoptimalkan keberadaan dan penggunaan TI untuk mendukung keberlangsungan proses bisnisnya. Hal tersebut berdampak pada pelayanan proses produksi tanaman pangan dan hortikultura yang tidak efektif dan efisien. Gejala permasalahan yang terjadi dikarenakan tidak terdapatnya suatu standar atau pedoman dalam menjalankan proses bisnis instansi dengan dukungan TI yang tepat. Dalam menjawab permasalahan tersebut, dibutuhkannya suatu pedoman dalam menyelenggarakan urusan bisnis sehingga dapat selaras dengan strategi TI. Metode yang digunakan yaitu perancangan suatu Enterprise Architecture (EA) dengan bantuan framework TOGAF (The Open Group Architecture Framework). Salah satu komponen TOGAF yaitu TOGAF ADM (Architecture Development Method), menjadi metodologi perancangan EA pada instansi. Fase-fase perancangan EA yang terdapat pada TOGAF ADM dimulai dari fase preliminary hingga fase migration planning. Perancangan arsitektur akan disesuaikan dengan kondisi dan kebutuhan bisnis instansi. Keluaran dari perancangan EA ini berupa artifak-artifak pada komponen TOGAF ADM, serta architecture roadmap sebagai rekomendasi penerapan dan pengembangan TI. Dengan adanya blueprint dari arsitektur tersebut, maka instansi dapat memiliki pedoman pelaksanaan proses bisnis dan penarikan keputusan dalam penerapan sistem informasi maupun teknologi yang akan digunakan dalam kurun waktu tertentu sesuai dengan kebutuhan instansi.
\end{abstract}

Kata kunci: enterprise architecture, TOGAF ADM, pemerintahan, pertanian, teknologi informasi.

\section{PENDAHULUAN}

Berdasarkan Peraturan Gubernur Jawa Barat Nomor 67 Tahun 2009, Dinas Tanaman Pangan dan Hortikultura Provinsi Jawa Barat (Distan Provinsi Jawa Barat) memiliki kewajiban dalam melaksanakan urusan pemerintahan daerah bidang pertanian tanaman pangan dan hortikultura berdasarkan asas otonomi, dekonsentrasi dan tugas pembantuan. Untuk keberlangsungan seluruh tugas dan kegiatan yang ada didalamnya, fungsi produksi tanaman pangan dan hortikultura dan juga Distan Provinsi Jawa Barat secara keseluruhan telah menerapkan Teknologi Informasi (TI) standar yang diterapkan pada setiap unit kerjanya. Namun, dalam hal pemenuhan kebutuhan TI yang tepat guna disetiap tugas-tugas pokoknya, Distan Provinsi Jawa Barat belum mampu mengoptimalkan penerapannya. Begitu pula untuk guideline atau pedoman penerapan dan perancangan TI yang belum terdapat pada Distan. Hal tersebut mengakibatkan terhambatnya keberlangsungan proses bisnis pada Distan, terutama untuk pelayanan publik aspek pertanian tanaman pangan dan hortikultura. Berfokus pada fungsi produksi tanaman pangan dan hortikultura, gejala-gejala permasalahan yang dirasakan akibat tidak terdapatnya guidline atau pedoman penerapan dan pengembangan TI yang tepat yaitu kesulitan dalam penyimpanan dan pengelolaan data dan dokumen yang diakibatkan karena belum terdapatnya suatu sistem informasi untuk manajemen data-data atau dokumen yang diperlukan dan dihasilkan dari suatu proses bisnis. Selain itu, masalah lain yang kerap dirasakan yang disebabkan oleh belum terdapatnya sistem informasi berupa aplikasi yang dapat melakukan tracking atau pemantauan dan penarikan informasi secara langsung mengenai komoditas, lokasi tanam, suhu, dsb. terhadap tanaman pangan dan hortikultura untuk kebutuhan perencanaan produksi. Ketiadaan sistem informasi seperti ini mengakibatkan pencarian atau pengambilan data membutuhkan waktu yang cukup lama dan mengakibatkan ketidakakuratan data.

Berdasarkan permasalahan dan gejala-gejala masalah yang dirasakan tersebut, fungsi produksi tanaman pangan dan hortikultura memerlukan suatu solusi berupa perancangan rinci mengenai penerapan teknologi informasi yang baik, dimana tetap sejalan dengan fungsi dan tujuan fungsi produksi tanaman pangan dan hortikultura. Integrasi yang sinergis antara bisnis, sistem informasi, dan teknologi pada instansi yang akan dirancang dapat dituangkan kedalam suatu perancangan yang disebut Enterprise Architecture (EA). Dimana ruang lingkup EA tidak hanya berfokus pada perencanaan dan 
pengelolaan bisnis perusahaan, namun bagaimana menyelaraskan strategi bisnis yang ada dengan teknologi informasi untuk melakukan perubahan dan mengelola inisiatif perubahan tersebut [2] Arsitektur enterprise diperlukan dalam upaya mendukung daya saing dan transformasi bisnis. Arsitektur enterprise ini bertujuan untuk membentuk keselarasan antara penerapan teknologi informasi terhadap bisnis bagi kebutuhan perusahaan [3]. Hasil atau output dari perancangan EA pada fungsi produksi tanaman pangan dan hortikultura yaitu adanya perancangan artefak dari setiap domain arsitektur dan suatu perancangan roadmap implementasi TI yang menggambarkan perencanaan dari pelaksanaan proyek TI.

\section{STUDI LITERATUR}

\section{A. Enterprise Architecture}

Enterprise Architecture (EA) merupakan sebuah blueprint atau cetak biru yang konseptual untuk mendefinisikan struktur dan operasi dari organisasi, dimana enterprise architecture bermaksud untuk menentukan bagaimana suatu organisasi dapat berjalan efektif dalam mencapai tujuan saat ini dan masa mendatang. Dalam artian terpisah, enterprise didefinisikan sebagai kumpulan dari organisasi yang memiliki serangkaian tujuan yang sama. Sedangakan architecture dalam konteks ini diartikan sebagai struktur dari komponenkomponen, hubungan antar komponen, dan prinsip-prinsip dan pedoman yang mengatur perancangan dan perubahan dari waktu ke waktu [1].

Makna Enterprise Architecture dideskripsikan sebagai key element yang membentuk organisasi dimana dimaksudkan untuk tercapainya keselarasan antar proses dan tujuan bisnis [4]. Dalam perancangan EA, dibutuhkan suatu framework agar pemodelan dapat terstruktur dan tepat. Terdapat beberapa jenis framework yang biasa digunakan dalam pemodelan EA, diantaranya yaitu Zachman framework, TOGAF (The Open Group Architecture Framework), FEAF (Federal Enterprise Architecture Framework), TEAF (Treasury Enterprise Architecture Framework), dan lainnya [5].

\section{B. TOGAF Framework}

Architecture framework merupakan struktur dasar, atau kumpulan struktur yang dapat digunakan untuk mengembangkan berbagai arsitektur yang berbeda. Dimana framework arsitektur digunakan untuk merancang target perusahaan pada satu set building blocks. TOGAF (The Open Group Architecture Framework) merupakan suatu framework arsitektur yang menyediakan metode dan tools untuk membantu dalam penerimaan, pembuatan, penggunaan, dan pemeliharaan EA. Dengan menggunakan TOGAF sebagai framework arsitektur, akan memungkinkan arsitekturarsitektur untuk dikembangkan secara konsisten, memenuhi kebutuhan stakeholder, memiliki sifat best practice, dan dapat mempertimbangkan dengan baik untuk kebutuhan-kebutuhan saat ini dan masa depan [1]. TOGAF memiliki tujuh komponen yang terdiri dari Architecture Development Method (ADM), Architecture Content Framework, Reference Models, ADM Guidelines and Techniques, Enterprise Continuum, dan Architecture Capability Framework.

\section{TOGAF ADM (Architecture Development Method)}

ADM merupakan metode generik yang berisi sekumpulan aktivitas yang digunakan dalam memodelkan pengembangan arsitektur enterprise. TOGAF ADM termasuk metode yang fleksibel yang dapat mengidentifikasi berbagai macam teknik pemodelan untuk perencanaan, karena metode ini dapat disesuaikan dengan perubahan dan kebutuhan selama perancangan dilakukan. TOGAF ADM dapat pula digunakan untuk merencanakan, merancang, mengembangkan, dan mengimplementasikan arsitektur sistem informasi untuk organisasi [6]. TOGAF mendefinisikan perusahaan sebagai kumpulan organisasi yang memiliki seperangkat tujuan yang sama. Perusahaan dapat berupa instansi pemerintahan, keseluruhan perusahaan, divisi perusahaan, departemen tunggal, atau organisasi-organisasi berbeda yang terhubung dengan kepemilikan yang sama [10].

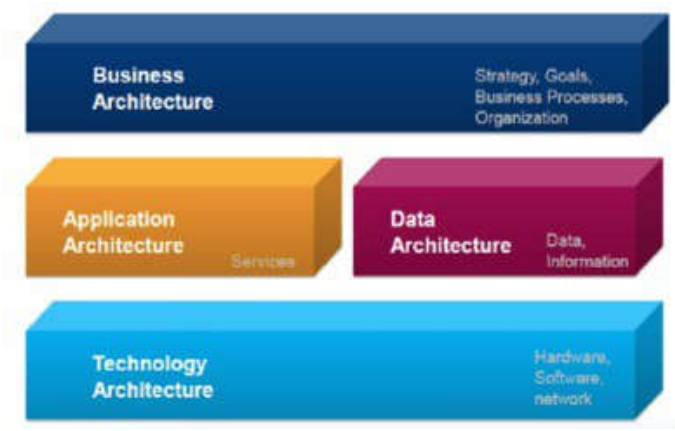

Gambar 1 Domain Arsitektur TOGAF ADM

The Open Group mengatakan bahwa TOGAF ADM menggambarkan suatu metode untuk mengembangkan dan mengelola siklus hidup suatu arsitektur enterprise dan membentuk inti dari TOGAF. TOGAF ADM memiliki delapan fase perancangan arsitektur, yaitu fase preliminary, architecture vision, business architecture, information system architecture (data architecture dan application architecture),, technology architecture, opportunities and solutions, migration planning, implementation governance, dan architecture change management, dengan terdapatnya requirement management pada setiap fasenya. Gambar 1 merupakan domain utama TOGAF ADM yang terdiri dari business architecture, data architecture, application architecture, dan technology architecture.

\section{METODOLOGI PENELITIAN}

\section{A. Model Konseptual}

Model konseptual mendefinisikan konsep-konsep dan kerangka berfikir yang terstruktur untuk dapat menyelesaikan permasalahan dan mencapai hasil yang diinginkan. Model konseptual berisi pendefinisian permasalahan, lingkungan, lingkup penelitian SI, dan knowledge base.

Pada bagian permasalahan, permasalahan yang terdapat pada penelitian dalam perancangan EA pada Distan Provinsi Jawa Barat khususnya pada fungsi produksi tanaman pangan dan hortikultura antara lain belum terdapatnya suatu sistem informasi untuk manajemen data atau dokumen pada fungsi produksi, belum terdapat suatu sistem yang terintegrasi untuk proses tukar menukar data antara pihak internal dan eksternal Distan Provinsi Jawa Barat, proses pengambilan dan penghantaran data masih dilakukan secara manual, 
dan belum terdapatnya sistem informasi berupa aplikasi yang dapat melakukan pemantauan dan penarikan informasi secara langsung terhadap proses produksi di lokasi pertanian.

Dari lingkup lingkungan, people atau pelaku yang terlibat yaitu Distan Provinsi Jawa Barat, Diskominfo, pegawai Distan Provinsi Jawa Barat, dan Kementrian Pertanian RI. Konsep penelitian ini yaitu melakukan perancangan EA menggunakan framework TOGAF ADM pada fungsi produksi tanaman pangan dan hortikultura Distan Provinsi Jawa Barat, dengan metode penelitian yaitu studi pustaka, interview, dan observasi secara langsung. Sedangkan TI artefak yang akan dihasilkan dari penelitian ini yaitu berupa catalog, matrix, dan diagram yang dihasilkan dari setiap fase perancangan dimulai dari tahap preliminary hingga migration planning.

\section{B. Sistematika Penelitian}

Sistematika penelitian bertujuan untuk memberikan acuan terhadap penelitian yang akan dilakukan, yaitu berisi tahapan dalam perancangan enterprise architecture. Tahapan tersebut terdiri dari tiga bagian, yaitu tahap persiapan dan identifikasi, tahap analisis dan perancangan, dan tahap kesimpulan. Tahap persiapan dan identifikasi berisi persiapan awal dan proses identifikasi penelitian. Kemudian dilaksanakan studi pustaka dan studi lapangan untuk mendapatkan informasi yang dibutuhkan. Tahap analisis dan perancangan akan dijabarkan kedalam fase TOGAF ADM, dimulai dari fase preliminary hingga fase migration planning. Terakhir yaitu tahap kesimpulan yang menggambarkan hasil dari tahap analisis dan perancangan yang berupa perancangan enterprise architecture, serta akan ditarik kesimpulan dan pemberian saran terhadap penelitian yang dilakukan.

\section{HASIL DAN ANALISIS}

\section{A. Fase Requirement Management}

Requirement management merupakan fase pendefinisian requirements atau kebutuhan-kebutuhan arsitektur pada domain utama TOGAF ADM yaitu business, data, application, dan technology dalam perancangan enterprise architecture. Requirement management sangat berguna untuk menentukan requirement atau kebutuhan dari suatu enterprise. Pemilihan TOGAF didasarkan pada beberapa kriteria untuk merancang arsitektur enterprise, yang pertama karena adanya requirement management yang tidak dimiliki oleh framework arsitektur enterprise lainnya [9].

Requirement berguna sebagai input dari setiap fase pada TOGAF ADM dalam menentukan arsitektur target sehingga arsitektur target yang dihasilkan sesuai dengan kebutuhan yang telah ditentukan di awal. Tabel I merupakan business requirement yang dipetakan sesuai kebutuhan bisnis pada fungsi produksi tanaman pangan dan hortikultura.

Tabel II merupakan data requirement yang dipetakan sesuai kebutuhan data pada fungsi produksi tanaman pangan dan hortikultura Distan Provinsi Jawa Barat.

Tabel III merupakan application requirement yang dipetakan sesuai kebutuhan aplikasi pada fungsi produksi tanaman pangan dan hortikultura Distan Provinsi Jawa Barat.
TABEL I

BUSINESS REQUIREMENT

\begin{tabular}{|c|l|}
\hline No. & \multicolumn{1}{|c|}{ Requirement } \\
\hline 1. & $\begin{array}{l}\text { Memiliki proses perencanaan program kerja yang sesuai dengan } \\
\text { rencana produksi Distan Provinsi Jawa Barat }\end{array}$ \\
\hline 2. & $\begin{array}{l}\text { Memiliki SOP kerja dan SOP budidaya bidang produksi tanaman } \\
\text { pangan dan hortikultura yang tepat guna }\end{array}$ \\
\hline 3. & $\begin{array}{l}\text { Terdapat proses penyimpanan dokumen yang baik sehingga tidak } \\
\text { terdapat kehilangan atau duplikasi dokumen produksi }\end{array}$ \\
\hline 4. & $\begin{array}{l}\text { Memiliki proses management dokumen yang tepat guna sehingga } \\
\text { dokumen produksi dapat dibuat, di-update, dilihat, dan dihapus } \\
\text { dengan semestinya }\end{array}$ \\
\hline 5. & $\begin{array}{l}\text { Mampu melaksanakan proses registrasi terhadap kelompok tani } \\
\text { yang ingin mendapatkan Surat Keterangan Registrasi (SKR) }\end{array}$ \\
\hline 6. & $\begin{array}{l}\text { Memiliki pelayanan/ bimbingan teknologi mengenai cara budidaya } \\
\text { produksi yang baik dan benar }\end{array}$ \\
\hline 7. & $\begin{array}{l}\text { Memiliki sistem budidaya yang baik dan tepat guna untuk } \\
\text { diterapkan oleh kelompok tani guna menghasilkan tanaman yang } \\
\text { bermutu }\end{array}$ \\
\hline 8. & $\begin{array}{l}\text { Memiliki proses koordinasi yang baik antar internal dinas maupun } \\
\text { eksternal guna mendukung proses produksi }\end{array}$ \\
\hline 9. & $\begin{array}{l}\text { Memiliki sistem pengawasan dan pengamanan terhadap tanaman } \\
\text { dan proses produksi tanaman yang mumpuni }\end{array}$ \\
\hline
\end{tabular}

TABEL II

DATA REQUIREMENT

\begin{tabular}{|c|l|}
\hline No. & \multicolumn{1}{|c|}{ Requirement } \\
\hline 1. & $\begin{array}{l}\text { Mampu menghasilkan data untuk perencanaan program kerja yang } \\
\text { akurat dan update }\end{array}$ \\
\hline 2. & $\begin{array}{l}\text { Dapat memastikan proses sharing data dan informasi berjalan } \\
\text { dengan baik untuk mendukung proses koordinasi produksi }\end{array}$ \\
\hline 3. & Telah terdapat sistem pengelolaan data yang efektif \\
\hline 4. & $\begin{array}{l}\text { Mampu mengolah dan menghasilkan data hasil kegiatan pada } \\
\text { fungsi produksi yang akurat (tepat) dan transparan }\end{array}$ \\
\hline 5. & $\begin{array}{l}\text { Mampu memastikan ketepatan data pemantauan terhadap kondisi } \\
\text { lapangan }\end{array}$ \\
\hline 6. & $\begin{array}{l}\text { Data dapat tersedia dan digunakan oleh pihak yang berkepentingan } \\
\text { apabila diperlukan }\end{array}$ \\
\hline
\end{tabular}

TABEL III

APPLICATION REQUIREMENT

\begin{tabular}{|l|l|}
\hline No. & \multicolumn{1}{c|}{ Requirement } \\
\hline 1. & $\begin{array}{l}\text { Aplikasi registrasi mudah digunakan } \text { user } \text { dan mampu mengelola } \\
\text { proses registrasi dengan efisien }\end{array}$ \\
\hline 2. & $\begin{array}{l}\text { Aplikasi registrasi mampu diakses oleh kelompok tani untuk proses } \\
\text { pengajuan registrasi }\end{array}$ \\
\hline 3. & $\begin{array}{l}\text { Terdapat aplikasi untuk mendukung keberlangsungan proses } \\
\text { perencanaan produksi }\end{array}$ \\
\hline 4. & $\begin{array}{l}\text { Terdapat aplikasi untuk mendukung keberlangsungan proses } \\
\text { koordinasi produksi }\end{array}$ \\
\hline 5. & $\begin{array}{l}\text { Terdapat aplikasi untuk pengelolaan data dan informasi yang } \\
\text { dihasilkan pada fungsi produksi }\end{array}$ \\
\hline
\end{tabular}

Tabel IV merupakan technology requirement yang dipetakan sesuai kebutuhan (pengelolaan) teknologi pada fungsi produksi tanaman pangan dan hortikultura Distan Provinsi Jawa Barat.

TABEL IV

TECHNOLOGYREQUIREMENT

\begin{tabular}{|l|l|}
\hline No. & \multicolumn{1}{c|}{ Requirement } \\
\hline 1 & Teknologi dapat mendukung proses bisnis pada fungsi produksi \\
\hline 2 & Teknologi dapat digunakan dengan mudah \\
\hline 3 & $\begin{array}{l}\text { Teknologi yang dimiliki telah terintegrasi baik di internal maupun } \\
\text { eksternal Distan Provinsi Jawa Barat }\end{array}$ \\
\hline 4 & Teknologi telah memiliki keamanan jaringan yang mumpuni \\
\hline 5 & Memiliki data center yang terpusat \\
\hline 6 & Terdapat mail server pada Distan Provinsi Jawa Barat \\
\hline
\end{tabular}




\section{B. Fase Preliminary}

Fase preliminary menggambarkan persiapan dan inisiasi aktivitas yang perlu dipersiapkan untuk memenuhi tujuan bisnis pada arsitektur enterprise yang baru, termasuk pendefinisian prinsip-prinsip arsitektur. Tabel $\mathrm{V}$ merupakan principles catalog mendeskripsikan prinsip-prinsip yang ada pada Distan Provinsi Jawa Barat yang dipetakan kedalam empat domain arsitektur yaitu prinsip arsitektur bisnis, prinsip arsitektur data, prinsip arsitektur aplikasi, dan prinsip arsitektur teknologi.

TABEL V

PRINCIPLES CATALOG

\begin{tabular}{|c|c|c|c|}
\hline No. & $\begin{array}{l}\text { Kategori } \\
\text { Principle }\end{array}$ & Principle & Deskripsi \\
\hline 1. & $\begin{array}{l}\text { Business } \\
\text { Principle }\end{array}$ & $\begin{array}{l}\text { Memaksimalkan } \\
\text { manfaat yang } \\
\text { didapatkan untuk } \\
\text { perusahaan }\end{array}$ & $\begin{array}{l}\text { Memberikan manfaat yang } \\
\text { maksimal untuk Distan } \\
\text { Provinsi Jawa Barat dengan } \\
\text { mengoptimalkan manajemen } \\
\text { proses bisnis yang ada, } \\
\text { sehingga proses yang } \\
\text { berlangsung dapat efektif dan } \\
\text { efisien. }\end{array}$ \\
\hline & & $\begin{array}{l}\text { Keberlangsungan } \\
\text { bisnis }\end{array}$ & $\begin{array}{l}\text { Keberlangsungan kegiatan } \\
\text { operasional bisnis pada Distan } \\
\text { Provinsi Jawa Barat tetap } \\
\text { berjalan meskipun terdapat } \\
\text { gangguan/ masalah pada } \\
\text { sistem. }\end{array}$ \\
\hline & & $\begin{array}{l}\text { Penggunaan } \\
\text { aplikasi umum }\end{array}$ & $\begin{array}{l}\text { Penggunaan aplikasi yang } \\
\text { bersifat umum digunakan } \\
\text { secara merata pada seluruh } \\
\text { bidang yang ada pada Distan } \\
\text { Provinsi Jawa Barat agar dapat } \\
\text { mendukung keberlangsungan } \\
\text { bisnis. }\end{array}$ \\
\hline & & $\begin{array}{l}\text { Kepatuhan } \\
\text { terhadap hukum }\end{array}$ & $\begin{array}{l}\text { Seluruh karyawan Distan } \\
\text { Provinsi Jawa Barat wajib } \\
\text { mentaati dasar hukum yang } \\
\text { berlaku bagi PNS (Pegawai } \\
\text { Negeri Sipil), seperti yang } \\
\text { terdapat pada PERDA RI No. } \\
\text { 53 Tahun } 2010 \text { tentang disiplin } \\
\text { PNS. }\end{array}$ \\
\hline \multirow{4}{*}{2.} & \multirow{4}{*}{$\begin{array}{c}\text { Data } \\
\text { Principle }\end{array}$} & Data adalah aset & $\begin{array}{lr}\text { Data merupakan aset penting } \\
\text { bagi Distan Provinsi Jawa } \\
\text { Barat yang perlu } & \text { dikelola } \\
\text { dengan baik dan } & \text { terjaga } \\
\text { kerahasiaannya } & \text { untuk } \\
\text { keberlangsungan } & \text { bisnis } \\
\text { instansi. } & \end{array}$ \\
\hline & & $\begin{array}{ll}\text { Data } & \text { dapat } \\
\text { diakses } & \end{array}$ & $\begin{array}{l}\text { Data dapat diakses oleh pihak } \\
\text { (baik internal atau eksternal) } \\
\text { yang berkepentingan atau } \\
\text { memiliki hak akses pada } \\
\text { Distan Provinsi Jawa Barat } \\
\text { untuk menjalankan fungsinya. }\end{array}$ \\
\hline & & Data terpercaya & $\begin{array}{lr}\text { Setiap elemen data } & \text { telah } \\
\text { terjamin asal-usul dan } \\
\text { kualitasnya, sehingga data } \\
\text { dapat digunakan dengan tepat } \\
\text { guna oleh pihak yang } \\
\text { berwenang. }\end{array}$ \\
\hline & & Keamanan data & $\begin{array}{l}\text { Keamanan data diperlukan } \\
\text { agar data terlindungi dari } \\
\text { penggunaan yang tidak } \\
\text { memiliki hak akses. }\end{array}$ \\
\hline
\end{tabular}

\begin{tabular}{|c|c|c|c|}
\hline No. & $\begin{array}{l}\text { Kategori } \\
\text { Principle }\end{array}$ & Principle & Deskripsi \\
\hline \multirow{5}{*}{3.} & \multirow{5}{*}{$\begin{array}{c}\text { Application } \\
\text { Principle }\end{array}$} & $\begin{array}{l}\text { Kemudahan } \\
\text { penggunaan }\end{array}$ & $\begin{array}{lr}\text { Kemudahan } & \text { dalam } \\
\text { penggunaan aplikasi (baik } \\
\text { aplikasi existing atau target) } \\
\text { diperlukan } \\
\text { mempermudah } \\
\text { keberlangsungan proses bisnis, } \\
\text { maka dari itu dibutuhkan } \\
\text { sosialisasi penggunaan } \\
\text { terhadap aplikasi atau dengan } \\
\text { terdapatnya buku manual } \\
\text { aplikasi. }\end{array}$ \\
\hline & & $\begin{array}{l}\text { Keamanan } \\
\text { aplikasi }\end{array}$ & $\begin{array}{l}\text { Keamanan terhadap aplikasi } \\
\text { dibutuhkan untuk mengontrol } \\
\text { hak akses dan alur komunikasi } \\
\text { data didalamnya. }\end{array}$ \\
\hline & & $\begin{array}{l}\text { Aplikasi tepat } \\
\text { guna }\end{array}$ & $\begin{array}{l}\text { Aplikasi yang ada atau akan } \\
\text { dirancang harus dapat } \\
\text { mendukung keberlangsungan } \\
\text { bisnis instansi. }\end{array}$ \\
\hline & & $\begin{array}{l}\text { Kemandirian } \\
\text { teknologi }\end{array}$ & $\begin{array}{l}\text { Aplikasi yang ada atau yang } \\
\text { akan dirancang dapat } \\
\text { beroperasi pada platform } \\
\text { teknologi yang terdapat pada } \\
\text { Distan guna. }\end{array}$ \\
\hline & & $\begin{array}{l}\text { Kebutuhan } \\
\text { berbasis } \\
\text { perubahan }\end{array}$ & $\begin{array}{l}\text { Aplikasi mampu menanggapi } \\
\text { perubahan dari kebutuhan } \\
\text { bisnis yang mungkin terjadi. }\end{array}$ \\
\hline \multirow{4}{*}{4.} & \multirow{4}{*}{$\begin{array}{l}\text { Technology } \\
\text { Principle }\end{array}$} & $\begin{array}{l}\text { Perubahan } \\
\text { penggunaan } \\
\text { teknologi }\end{array}$ & $\begin{array}{l}\text { Perubahan penggunaan dan } \\
\text { pengelolaan teknologi } \\
\text { disesuaikan dengan kebutuhan } \\
\text { teknologi bagi Distan Provinsi } \\
\text { Jawa Barat. }\end{array}$ \\
\hline & & $\begin{array}{l}\text { Keefektifitasan } \\
\text { penerapan } \\
\text { teknologi }\end{array}$ & $\begin{array}{l}\text { Teknologi yang digunakan dan } \\
\text { yang akan diterapkan dapat } \\
\text { efektif dalam mendukung } \\
\text { keperluan aplikasi. }\end{array}$ \\
\hline & & $\begin{array}{l}\text { Keamanan } \\
\text { teknologi }\end{array}$ & $\begin{array}{lr}\begin{array}{l}\text { Kemanan } \\
\text { dibutuhkan }\end{array} & \begin{array}{r}\text { teknologi } \\
\text { demi }\end{array} \\
\text { berlangsungnya bisnis, seperti } \\
\text { keamanan jaringan dan server } \\
\text { yang ada pada Distan Provinsi } \\
\text { Jawararat. } & \text { Sehingga } \\
\text { teknologi } & \text { sepatutnya } \\
\text { digunakan } & \text { berdasarkan } \\
\text { prosedur. }\end{array}$ \\
\hline & & $\begin{array}{l}\text { Keberagaman } \\
\text { kontrol teknis }\end{array}$ & $\begin{array}{l}\text { Melakukan kontrol terhadap } \\
\text { keberagaman teknologi yang } \\
\text { diterapkan dibutuhkan agar } \\
\text { dapat mengurangi } \\
\text { permasalahan yang mungkin } \\
\text { terjadi. }\end{array}$ \\
\hline
\end{tabular}

\section{Fase Business Architecture}

Fase business architecture menggambarkan pengembangan dan pendefinisian arsitektur bisnis untuk mendukung architecture vision. Mengembangkan target arsitektur bisnis yang menjelaskan bagaimana pelaksanaan kebutuhan perusahaan untuk mencapai tujuan bisnis dalam mendukung Architecture Vision yang telah disetujui [7]. Tabel VI merupakan process flow catalog yang berisi pemetaan list dari fungsi pada penelitian ini yaitu fungsi produksi tanaman pangan dan hortikultura, layanan bisnis atau business service yang dimiliki, serta proses bisnis atau business process yang dimiliki setiap layanan bisnisnya. 
Berdasarkan Tabel VI dapat dilihat bahwa pada fungsi produksi tanaman pangan dan hortikultura terdapat enam proses bisnis. Proses bisnis utama terdiri dari proses persiapan program produksi, proses administrasi dan pelayanan publik aspek produksi, dan proses fasilitasi produksi. Dimana pada proses persiapan program produksi terdapat proses bisnis penyusunan program kerja produksi dan perencanaan SOP budidaya produksi. Pada proses bisnis administrasi dan pelayanan publik aspek produksi terdapat proses pengelolaan registrasi dan proses pelaksanaan bimbingan teknis budidaya. Terakhir, pada proses fasilitasi produksi terdapat proses pelaksanaan koordinasi dan proses pengajuan budidaya produksi.

TABEL VI

PROCESS FLOW CATALOG

\begin{tabular}{|c|c|c|}
\hline Function & Business Service & Business Process \\
\hline \multirow{6}{*}{$\begin{array}{l}\text { Produksi Tanaman } \\
\text { Pangan dan } \\
\text { Hortikultura }\end{array}$} & \multirow[t]{2}{*}{$\begin{array}{l}\text { Persiapan Program } \\
\text { Produksi }\end{array}$} & $\begin{array}{l}\text { Penyusunan Program } \\
\text { Kerja Produksi }\end{array}$ \\
\hline & & $\begin{array}{l}\text { Perencanaan SOP } \\
\text { Budidaya Produksi }\end{array}$ \\
\hline & \multirow{2}{*}{$\begin{array}{l}\text { Administrasi dan } \\
\text { Pelayanan Publik } \\
\text { Aspek Produksi }\end{array}$} & Pengelolaan Registrasi \\
\hline & & $\begin{array}{l}\text { Pengajuan Budidaya } \\
\text { Produksi }\end{array}$ \\
\hline & \multirow[t]{2}{*}{ Fasilitasi Produksi } & Pelaksanaan Koordinasi \\
\hline & & $\begin{array}{l}\text { Pelaksanaan Bimbingan } \\
\text { Teknis Budidaya }\end{array}$ \\
\hline
\end{tabular}

\section{Fase Information System Architecture}

Fase information system architecture terdiri dari data architecture dan application architecture, dimana bertujuan untuk menggambarkan perancangan arsitektur sistem informasi target untuk fungsi produksi tanaman pangan dan hortikultura. Arsitektur data bertujuan untuk mengidentifikasi dan mendefinisikan jenis-jenis data utama atau entitas data yang diperlukan bagi enterprise guna mendukung fungsi-fungsi bisnis yang telah didefinisikan pada tahap pemodelan bisnis kemudian merelasikan entitas data tersebut dengan fungsi bisnis enterprise .Sedangkan rsitektur aplikasi bertujuan untuk mengidentifikasi dan mendefinisikan jenis-jenis aplikasi utama yang dibutuhkan untuk mengelola data dan mendukung fungsi bisnis enterprise, kemudian merelasikan aplikasi dengan fungsi bisnis enterprise [9].

Dalam pendefinisian entitas-entitas data yang dimiliki fungsi produksi tanaman pangan dan hortikultura, dilakukan pembuatan katalog yang berisi pemetaan entitas data (logical data), physical data, dan tipe dari entitas data tersebut. Tabel VII merupakan data entity catalog, dengan entitas data target yang dihasilkan dari perencanaan penerapan aplikasi target dengan pemberian highlight warna berbeda.

Melalui application portfolio catalog akan didefinisikan penggunaan aplikasi existing (Aplikasi Registrasi Kementan) dan aplikasi target yang akan dikembangkan pada fungsi produksi tanaman pangan dan hortikultura. Pada target arsitektur aplikasi, terdapat pengembangan terhadap aplikasi existing yang telah ada. Berdasarkan analisis target perancangan aplikasi yang didasari oleh permasalahan dan kebutuhan fungsi produksi tanaman pangan dan hortikultura, maka dapat disimpulkan aplikasi target yang akan dirancang dan terapkan antara lain yaitu aplikasi E-Registration, aplikasi DMS (Document Management System) Produksi, aplikasi ETracking, dan aplikasi Location Report. Tabel VIII akan mendeskripsikan logical dan physical component dari aplikasi target yang akan dirancang beserta deskripsi aplikasi.

TABEL VII

DATA ENTITY CATALOG

\begin{tabular}{|c|c|c|c|c|}
\hline No & $\begin{array}{c}\text { Entitas } \\
\text { (Logical } \\
\text { Data) }\end{array}$ & $\begin{array}{c}\text { Physical } \\
\text { Data }\end{array}$ & Deskripsi & Tipe \\
\hline 1. & $\begin{array}{l}\text { Kelompok } \\
\text { Tani }\end{array}$ & $\begin{array}{l}\text { Kelompok } \\
\text { _Tani }\end{array}$ & $\begin{array}{l}\text { Berisi daftar data } \\
\text { kelompok tani yang telah } \\
\text { terdaftar }\end{array}$ & $\begin{array}{l}\text { Transaction } \\
\text { al Data }\end{array}$ \\
\hline 2. & Bidang & Bidang & $\begin{array}{l}\text { Berisi data bidang yang } \\
\text { ada pada Distan Provinsi } \\
\text { Jawa Barat }\end{array}$ & $\begin{array}{l}\text { Transaction } \\
\text { al Data }\end{array}$ \\
\hline 3. & Pegawai & Pegawai & $\begin{array}{l}\text { Berisi data identitas } \\
\text { pegawai pada suatu } \\
\text { bidang terhadap fungsi }\end{array}$ & $\begin{array}{l}\text { Master } \\
\text { Data }\end{array}$ \\
\hline 4. & $\begin{array}{l}\text { Rencana } \\
\text { Kegiatan }\end{array}$ & $\begin{array}{l}\text { Rencana } \\
\text { Kegiatan }\end{array}$ & $\begin{array}{l}\text { Menjelaskan sekumpulan } \\
\text { data rencana dari } \\
\text { kegiatan yang difasilitasi } \\
\text { oleh APBN dan APBD }\end{array}$ & $\begin{array}{l}\text { Transaction } \\
\text { al Data }\end{array}$ \\
\hline 5. & $\begin{array}{l}\text { Pedoman } \\
\text { Budidaya }\end{array}$ & $\begin{array}{l}\text { Pedoman } \\
\text { Budidaya }\end{array}$ & $\begin{array}{l}\text { Berisi sekumpulan data } \\
\text { untuk melakukan } \\
\text { pelaksanaan budidaya } \\
\text { tanaman }\end{array}$ & $\begin{array}{l}\text { Transaction } \\
\text { al Data }\end{array}$ \\
\hline 6. & $\begin{array}{l}\text { Hasil } \\
\text { Registrasi }\end{array}$ & $\begin{array}{l}\text { Hasil_Reg } \\
\text { istrasi }\end{array}$ & $\begin{array}{l}\text { Merupakan data registrasi } \\
\text { dimana terdapat } \\
\text { kelompok tani yang lolos } \\
\text { seleksi untuk } \\
\text { mendapatkan SKR dan } \\
\text { yang tidak }\end{array}$ & $\begin{array}{l}\text { Master } \\
\text { Data }\end{array}$ \\
\hline 7. & $\begin{array}{l}\text { Program } \\
\text { Kerja } \\
\text { Produksi }\end{array}$ & $\begin{array}{l}\text { Program_- } \\
\text { Kerja_Pro } \\
\text { duksi }\end{array}$ & $\begin{array}{l}\text { Menjelaskan draft } \\
\text { rencana dan program } \\
\text { kerja fungsi produksi }\end{array}$ & $\begin{array}{l}\text { Transaction } \\
\text { al Data }\end{array}$ \\
\hline 8. & Pengajuan & Pengajuan & $\begin{array}{l}\text { Berisi data permohonan/ } \\
\text { pengajuan untuk } \\
\text { administrasi publik fungsi } \\
\text { produksi dan pengadaan }\end{array}$ & $\begin{array}{l}\text { Transaction } \\
\text { al Data }\end{array}$ \\
\hline 9. & $\begin{array}{l}\text { Dokument } \\
\text { asi } \\
\text { Kegiatan }\end{array}$ & $\begin{array}{l}\text { Dokument } \\
\text { asi_Kegia } \\
\text { tan }\end{array}$ & $\begin{array}{l}\text { Merupakan data hasil } \\
\text { pelaksanaan suatu } \\
\text { kegiatan pada fungsi } \\
\text { produksi dalam bentuk } \\
\text { berita acara }\end{array}$ & $\begin{array}{l}\text { Transaction } \\
\text { al Data }\end{array}$ \\
\hline 10. & $\begin{array}{l}\text { Komodita } \\
\text { s }\end{array}$ & $\begin{array}{l}\text { Komodita } \\
\text { s }\end{array}$ & $\begin{array}{l}\text { Berisi data jenis } \\
\text { komoditas dan nama } \\
\text { komoditas tanaman } \\
\end{array}$ & $\begin{array}{l}\text { Master } \\
\text { Data }\end{array}$ \\
\hline 11. & $\begin{array}{l}\text { Lahan } \\
\text { Pertanian }\end{array}$ & $\begin{array}{l}\text { Lahan_Pe } \\
\text { rtanian }\end{array}$ & $\begin{array}{l}\text { Berisi data kondisi lahan } \\
\text { pertanian yang meliputi } \\
\text { jenis dan suhu tanah }\end{array}$ & $\begin{array}{l}\text { Master } \\
\text { Data }\end{array}$ \\
\hline 12. & Pemohon & Pemohon & $\begin{array}{l}\text { Berisi data kelompok tani } \\
\text { yang melakukan } \\
\text { pengajuan atau } \\
\text { permohonan untuk } \\
\text { mengikuti registrasi dan } \\
\text { program budidaya }\end{array}$ & $\begin{array}{l}\text { Transaction } \\
\text { al Data }\end{array}$ \\
\hline 13. & Registrasi & Registrasi & $\begin{array}{l}\text { Merupakan data seputar } \\
\text { pengelolaan registrasi } \\
\text { tanaman dan lahan } \\
\text { pertanian }\end{array}$ & $\begin{array}{l}\text { Transaction } \\
\text { al Data }\end{array}$ \\
\hline 14. & $\begin{array}{l}\text { Pemeriksa } \\
\text { an } \\
\text { Lapangan }\end{array}$ & $\begin{array}{l}\text { Pemeriksa } \\
\text { an_Lapan } \\
\text { gan }\end{array}$ & $\begin{array}{l}\text { Berisi data hasil } \\
\text { pemeriksaan lapangan } \\
\text { dalam proses } \\
\text { penyeleksian registrasi }\end{array}$ & $\begin{array}{l}\text { Transaction } \\
\text { al Data }\end{array}$ \\
\hline 15. & CPCL & CPCL & $\begin{array}{l}\text { Berisi data calon } \\
\text { kelompok tani dan calon } \\
\text { lahan pertanian }\end{array}$ & $\begin{array}{l}\text { Master } \\
\text { Data }\end{array}$ \\
\hline
\end{tabular}




\begin{tabular}{|c|c|c|c|c|}
\hline No & $\begin{array}{l}\text { Entitas } \\
\text { (Logical } \\
\text { Data) }\end{array}$ & $\begin{array}{c}\text { Physical } \\
\text { Data }\end{array}$ & Deskripsi & Tipe \\
\hline 16. & $\begin{array}{l}\text { Bimbinga } \\
\mathrm{n} \text { Teknis }\end{array}$ & $\begin{array}{l}\text { Bimbinga } \\
\mathrm{n} \_ \text {Teknis }\end{array}$ & $\begin{array}{l}\text { Berisi data } \\
\text { penyelenggaraan kegiatan } \\
\text { bimbingan teknis } \\
\text { budidaya tanaman }\end{array}$ & $\begin{array}{l}\text { Transaction } \\
\text { al Data }\end{array}$ \\
\hline 17. & $\begin{array}{l}\text { Pengadaa } \\
\mathrm{n}\end{array}$ & $\begin{array}{l}\text { Pengadaa } \\
\mathrm{n}\end{array}$ & $\begin{array}{l}\text { Berisi data pengajuan } \\
\text { pengadaan untuk } \\
\text { mengatasi permasalahan } \\
\text { yang ada dimana } \\
\text { mendukung proses } \\
\text { koordinasi produksi }\end{array}$ & $\begin{array}{l}\text { Master } \\
\text { Data }\end{array}$ \\
\hline 18. & $\begin{array}{l}\text { Pembayar } \\
\text { an }\end{array}$ & $\begin{array}{l}\text { Pembayar } \\
\text { an }\end{array}$ & $\begin{array}{l}\text { Merupakan data dari } \\
\text { transaksi pembayaran } \\
\text { yang diberikan oleh } \\
\text { Distan Kab/Kota terhadap } \\
\text { CPCL }\end{array}$ & $\begin{array}{l}\text { Transaction } \\
\text { al Data }\end{array}$ \\
\hline 19. & $\begin{array}{l}\text { Notifikasi } \\
\text { Registrasi }\end{array}$ & $\begin{array}{l}\text { Notifikasi } \\
\bar{i}^{\text {Registras }}\end{array}$ & $\begin{array}{l}\text { Berisi data perberitahuan } \\
\text { bahwa SKR (Surat } \\
\text { Keterangan Registrasi) } \\
\text { telah selesai diproses } \\
\text { (dihasilkan dari aplikasi } \\
\text { target } e \text {-registration) }\end{array}$ & $\begin{array}{l}\text { Master } \\
\text { Data }\end{array}$ \\
\hline 20 & $\begin{array}{l}\text { Laporan } \\
\text { Permasala } \\
\text { han }\end{array}$ & $\begin{array}{l}\text { Pelaporan } \\
\text { Permasal } \\
\text { ahan }\end{array}$ & $\begin{array}{l}\text { Berisi data dari laporan } \\
\text { permasalahan hasil proses } \\
\text { koordinasi di lokasi } \\
\text { pertanian (dihasilkan dari } \\
\text { adanya aplikasi target } \\
\text { location report) }\end{array}$ & $\begin{array}{l}\text { Transaction } \\
\text { al Data }\end{array}$ \\
\hline
\end{tabular}

TABEL VIII

APPLICATION PORTFOLIO CATALOG

\begin{tabular}{|c|c|c|}
\hline $\begin{array}{l}\text { Logical Application } \\
\text { Component }\end{array}$ & $\begin{array}{c}\text { Physical Application } \\
\text { Component }\end{array}$ & Keterangan \\
\hline $\begin{array}{l}\text { Pengelolaan Nomor } \\
\text { SKR }\end{array}$ & Registrasi Kementan & $\begin{array}{l}\text { Aplikasi untuk } \\
\text { mengelola pembuatan } \\
\text { nomor Surat } \\
\text { Keterangan Registrasi } \\
\text { (SKR) }\end{array}$ \\
\hline $\begin{array}{l}\text { Pengelolaan } \\
\text { Pengajuan Registrasi }\end{array}$ & \multirow[t]{3}{*}{ E-Registration } & \multirow{3}{*}{$\begin{array}{l}\text { Aplikasi untuk } \\
\text { mengelola pengajuan } \\
\text { registrasi hingga } \\
\text { menghasilkan Surat } \\
\text { Keterangan Registrasi. }\end{array}$} \\
\hline $\begin{array}{l}\text { Pengelolaan Nomor } \\
\text { SKR }\end{array}$ & & \\
\hline $\begin{array}{l}\text { Pengelolaan } \\
\text { Notifikasi Registrasi }\end{array}$ & & \\
\hline $\begin{array}{l}\text { Pengelolaan } \\
\text { Dokumen Produksi }\end{array}$ & \multirow[t]{3}{*}{ DMS Produksi } & \multirow{3}{*}{$\begin{array}{l}\text { Aplikasi untuk } \\
\text { mengelola } \\
\text { data/dokumen yang } \\
\text { (akan) dihasilkan dari } \\
\text { suatu kegiatan. }\end{array}$} \\
\hline $\begin{array}{l}\text { Digitalisasi Dokumen } \\
\text { Produksi }\end{array}$ & & \\
\hline Sharing Dokumen & & \\
\hline $\begin{array}{l}\text { Pengelolaan } \\
\text { Informasi Produksi }\end{array}$ & \multirow[t]{3}{*}{ E-Tracking } & \multirow{3}{*}{$\begin{array}{l}\text { Aplikasi untuk } \\
\text { pemantauan volume } \\
\text { produksi, pemantauan } \\
\text { tanaman, dan kondisi } \\
\text { lahan pada suatu } \\
\text { daerah. }\end{array}$} \\
\hline $\begin{array}{l}\text { Pengelolaan } \\
\text { Informasi Komoditas }\end{array}$ & & \\
\hline $\begin{array}{l}\text { Pengelolaan } \\
\text { Informasi Kondisi } \\
\text { Lahan }\end{array}$ & & \\
\hline $\begin{array}{l}\text { Pengelolaan } \\
\text { Informasi Lapangan }\end{array}$ & \multirow[t]{2}{*}{ Location Report } & \multirow{2}{*}{$\begin{array}{l}\text { Aplikasi untuk } \\
\text { melakukan pelaporan } \\
\text { oleh petugas lapangan } \\
\text { terhadap kondisi/ } \\
\text { permasalahan kepada } \\
\text { Kasi Produksi di setiap } \\
\text { lokasi pertanian. }\end{array}$} \\
\hline $\begin{array}{l}\text { Pengelolaan } \\
\text { Pelaporan Lapangan }\end{array}$ & & \\
\hline
\end{tabular}

\section{E. Fase Technology Architecture}

Technology Architecture merupakan infrastruktur yang diperlukan untuk mendukung pengelolaan data dan aplikasi yang terdapat pada organisasi atau perusahaan [8]. Technology standards catalog merupakan saah satu katalog yang mendefinisikan standar-standar instansi berdasarkan platform service yang memetakan logical technology component dan physical technology component yang terlibat. Tabel IX merupakan technology standard catalog yang ada pada Distan Provinsi Jawa Barat (tidak ada perubahan untuk technology standard catalog target).

TABEL IX

TECHNOLOGY STANDARDS CATALOG

\begin{tabular}{|c|l|l|}
\hline Platform Service & \multicolumn{1}{|c|}{$\begin{array}{c}\text { Logical Technology } \\
\text { Component }\end{array}$} & \multicolumn{1}{|c|}{$\begin{array}{c}\text { Physical Technology } \\
\text { Component }\end{array}$} \\
\hline \multirow{5}{*}{$\begin{array}{c}\text { Operating } \\
\text { System } \\
\text { Server Operating } \\
\text { System }\end{array}$} & $\begin{array}{l}\text { Network Operating } \\
\text { System }\end{array}$ & $\begin{array}{l}\text { Linux } \\
\text { (Ubuntu, CentOS, } \\
\text { Backtrack) }\end{array}$ \\
\cline { 2 - 3 } & $\begin{array}{l}\text { Client Operating } \\
\text { System }\end{array}$ & $\begin{array}{l}\text { Microsoft Windows } \\
\text { (Series 7,8,8.1,10) }\end{array}$ \\
\hline \multirow{5}{*}{$\begin{array}{c}\text { Interchata } \\
\text { Comme } \\
\text { Network }\end{array}$} & File & DMS \\
\cline { 2 - 3 } & Web Service & API \\
\cline { 2 - 3 } & Web Server & Apache \\
\cline { 2 - 3 } & Database Server & MySQL Server \\
\cline { 2 - 3 } & Mail Server & Foogle Cloud Platform \\
\hline \multirow{2}{*}{ Security } & Firewall & Next Generation Firewall \\
\hline
\end{tabular}

Technology portfolio catalog merupakan katalog yang berfungsi untuk mendefinisikan seluruh komponen teknogi yang terdiri dari perangkat keras, perangkat lunak, infrastruktur perangkat lunak, dan aplikasi perangkat lunak. Tabel X merupakan technology standard catalog pada Distan Provinsi Jawa Barat.

TABEL X

TECHNOLOGY PORTFOLIO CATALOG

\begin{tabular}{|c|c|c|l|}
\hline Type & Product Name & Vendor & \multicolumn{1}{|c|}{ Description } \\
\hline PC / Laptop & Applikasi Klien & - & $\begin{array}{l}\text { Aplikasi yang } \\
\text { digunakan oleh } \\
\text { karyawan sebagai } \\
\text { penunjang pekerjaan. }\end{array}$ \\
\hline Router & ISP Router & Skyline & $\begin{array}{l}\text { Digunakan sebagai } \\
\text { alat koneksi dengan } \\
\text { provider } \text { ISP }\end{array}$ \\
& Router & MIKROTIK & $\begin{array}{l}\text { Merupakan router } \\
\text { utama untuk LAN }\end{array}$ \\
\cline { 2 - 4 } & Mail Server & HP ProLiant & $\begin{array}{l}\text { Digunakan untuk } \\
\text { pengaksesan } \\
\text { surat/mail }\end{array}$ \\
\cline { 2 - 4 } & Web Server & $\begin{array}{l}\text { Merupakan server } \\
\text { yang digunakan } \\
\text { untuk meletakkan } \\
\text { aplikasi berbasis } \\
\text { website }\end{array}$ \\
\cline { 2 - 4 } & & & \\
\hline
\end{tabular}




\begin{tabular}{|c|c|c|c|}
\hline Type & Product Name & Vendor & Description \\
\hline & $\begin{array}{c}\text { Database } \\
\text { Server }\end{array}$ & & $\begin{array}{l}\text { Merupakan server } \\
\text { yang digunakan } \\
\text { sebagai wadah } \\
\text { database seluruh } \\
\text { aplikasi yang } \\
\text { berbasis MySQL } \\
\text { yang telah di } \\
\text { integrasikan dengan } \\
\text { semua aplikasi } \\
\text { website }\end{array}$ \\
\hline & File Server & & $\begin{array}{l}\text { Merupakan Server } \\
\text { untuk meletakkan } \\
\text { dokumen transaksi } \\
\text { yang masih } \\
\text { digunakan }\end{array}$ \\
\hline & $\begin{array}{c}\text { Data } \\
\text { Warehouse }\end{array}$ & & $\begin{array}{l}\text { Merupakan server } \\
\text { yang digunakan } \\
\text { untuk meletakkan } \\
\text { dokumen lampau } \\
\text { yang tidak } \\
\text { ditransaksikan lagi }\end{array}$ \\
\hline \multirow[t]{2}{*}{ Switch } & $\begin{array}{l}\text { Distribution } \\
\text { Switch }\end{array}$ & $\begin{array}{c}\text { D-LINK } \\
\text { DES-1008D }\end{array}$ & $\begin{array}{l}\text { Switch yang } \\
\text { digunakan oleh } \\
\text { aplikasi klien pada } \\
\text { LAN di Distan }\end{array}$ \\
\hline & Access Switch & $\begin{array}{c}\text { D-LINK } \\
\text { DES-1008D }\end{array}$ & $\begin{array}{l}\text { Switch yang } \\
\text { digunakan untuk } \\
\text { mengakses jaringan } \\
\text { di Dinas }\end{array}$ \\
\hline $\begin{array}{c}\text { Access } \\
\text { Point }\end{array}$ & Access Point & D -LINK & $\begin{array}{l}\text { Digunakan untuk } \\
\text { sharing jaringan } \\
\text { internet dari lan } \\
\text { menajdi wifi }\end{array}$ \\
\hline
\end{tabular}

\section{F. Fase Opportunities and Solutions}

Fase opportunities and solutions merupakan tahap perencanaan implementasi awal dan pengidentifikasian sarana penghantaran dari arsitektur yang telah didefinisikan. Pada tahapan ini lebih menekankan pada manfaat yang diperoleh dari arsitektur enterprise yang meliputi arsitektur bisnis, arsitektur data, arsitektur aplikasi, dan arsitektur teknologi, sehingga menjadi dasar bagi stakeholder untuk memilih dan menentukan arsitektur yang akan diimplementasikan. Untuk memodelkan opportunities and solutions dalam rancangan bisa menggunakan teknik Project Context Diagram dan Benefit Diagram [9].

Salah satu output dari opportunities and solutions adalah perancangan diagram benefit diagram. Benefit diagram merupakan diagram yang memetakan setiap objective, solution, outcome, measurement, dan benefit yang dihasilkan dari penerapan aplikasi target dan pengembangan aplikasi existing yang telah didefinisikan pada fase sebelumnya. Tabel XI merupakan daftar list dari benefit diagram.

TABEL XI

BENEFIT DIAGRAM TABLE LIST

\begin{tabular}{|l|l|l|l|l|l|}
\hline No & \multicolumn{1}{|c|}{ Benefit } & \multicolumn{1}{|c|}{ Objective } & \multicolumn{1}{|c|}{ Solution } & Outcome & Measurement \\
\hline 1. & Memiliki & Mampu & Adanya & Proses & Persentase \\
& $\begin{array}{l}\text { program } \\
\text { kerja } \\
\text { produksi } \\
\text { yang }\end{array}$ & $\begin{array}{l}\text { melaksanaka } \\
\text { n proses } \\
\text { perencanaan } \\
\text { dan }\end{array}$ & $\begin{array}{l}\text { aplikasi } E- \\
\text { Tracking } \\
\text { untuk }\end{array}$ & $\begin{array}{l}\text { an } \\
\text { dokumen } \\
\text { produksi }\end{array}$ & $\begin{array}{l}\text { ketidakakurata } \\
\text { nerencanaan }\end{array}$ \\
\hline
\end{tabular}

\begin{tabular}{|c|c|c|c|c|c|}
\hline No & Benefit & Objective & Solution & Outcome & Measurement \\
\hline & $\begin{array}{l}\text { sesuai dan } \\
\text { memiliki } \\
\text { sistem } \\
\text { pengelolaa } \\
\mathrm{n} \\
\text { dokumen } \\
\text { produksi } \\
\text { yang baik }\end{array}$ & $\begin{array}{l}\text { pengelolaan } \\
\text { produksi } \\
\text { tanaman } \\
\text { pangan dan } \\
\text { hortikultura } \\
\text { dengan baik }\end{array}$ & $\begin{array}{l}\text { pemantauan } \\
\text { kebutuhan } \\
\text { perencanaan } \\
\text { produksi, } \\
\text { dan } \\
\text { penerapan } \\
\text { aplikasi } \\
\text { DMS } \\
\text { Produksi }\end{array}$ & $\begin{array}{l}\text { lebih } \\
\text { efektif } \\
\text { dan } \\
\text { menghasil } \\
\text { kan data } \\
\text { untuk } \\
\text { kebutuhan } \\
\text { perencana } \\
\text { an } \\
\text { produksi } \\
\text { yang tepat } \\
\text { guna }\end{array}$ & $\begin{array}{l}\text { produksi akan } \\
\text { berkurang }\end{array}$ \\
\hline 2. & $\begin{array}{l}\text { Aplikasi } \\
\text { registrasi } \\
\text { untuk } \\
\text { kelompok } \\
\text { tani dapat } \\
\text { berfungsi } \\
\text { secara } \\
\text { maksimal } \\
\text { dan } \\
\text { memudah } \\
\text { kan } \\
\text { keberlangs } \\
\text { ungan } \\
\text { proses } \\
\text { bisnis }\end{array}$ & $\begin{array}{l}\text { Melakukan } \\
\text { pelayanan } \\
\text { dan } \\
\text { administrasi } \\
\text { aspek } \\
\text { produksi } \\
\text { tanaman } \\
\text { pangan dan } \\
\text { hortikultura } \\
\text { kepada } \\
\text { kelompok } \\
\text { tani }\end{array}$ & $\begin{array}{l}\text { Adanya } \\
\text { pengembang } \\
\text { an } \\
\text { fungsionalit } \\
\text { as aplikasi } \\
\text { E- } \\
\text { Registration } \\
\text { exsisting }\end{array}$ & $\begin{array}{l}\text { Proses } \\
\text { pengajuan } \\
\text { registrasi } \\
\text { oleh } \\
\text { kelompok } \\
\text { tani lebih } \\
\text { mudah } \\
\text { dilakukan } \\
\text { dan } \\
\text { kesalahan } \\
\text { teknis } \\
\text { pada } \\
\text { aplikasi } \\
\text { existing } \\
\text { telah } \\
\text { berkurang }\end{array}$ & $\begin{array}{l}\text { Penggunaan } \\
\text { aplikasi } E \text { - } \\
\text { Registration } \\
\text { target telah } \\
\text { dapat } \\
\text { digunakan } \\
\text { oleh bagian } \\
\text { Produksi } \\
\text { Tanaman } \\
\text { Pangan } \\
\text { dimana } \\
\text { sebelumnya } \\
\text { hanya dapat } \\
\text { diakses oleh } \\
\text { bagian } \\
\text { Produksi } \\
\text { Tanaman } \\
\text { Hortikultura }\end{array}$ \\
\hline 3. & $\begin{array}{l}\text { Keberlang } \\
\text { sungan } \\
\text { proses } \\
\text { produksi } \\
\text { dan } \\
\text { pengaman } \\
\text { an } \\
\text { tanaman } \\
\text { pangan } \\
\text { dan } \\
\text { hortikultur } \\
\text { a di } \\
\text { lapangan } \\
\text { dapat } \\
\text { terkendali }\end{array}$ & $\begin{array}{l}\text { Memfasilita } \\
\text { si proses } \\
\text { produksi } \\
\text { tanaman } \\
\text { pangan dan } \\
\text { hortikultura } \\
\text { guna } \\
\text { meningkatka } \\
\text { n hasil } \\
\text { produksi } \\
\text { dan } \\
\text { menghasilka } \\
\text { n tanaman } \\
\text { yang } \\
\text { berkualitas } \\
\text { dan } \\
\text { memiliki } \\
\text { nilai tambah }\end{array}$ & $\begin{array}{l}\text { Adanya } \\
\text { penerapan } \\
\text { aplikasi } \\
\text { Location } \\
\text { Report } \\
\text { dalam } \\
\text { proses } \\
\text { koordinasi } \\
\text { untuk } \\
\text { memantau } \\
\text { kondisi } \\
\text { lapangan }\end{array}$ & $\begin{array}{l}\text { Memperm } \\
\text { udah } \\
\text { proses } \\
\text { pemantau } \\
\text { an kondisi } \\
\text { produksi } \\
\text { oleh } \\
\text { petugas } \\
\text { lapangan } \\
\text { yang } \\
\text { berada di } \\
\text { lokasi } \\
\text { pertanian } \\
\text { yang } \\
\text { berbeda- } \\
\text { beda }\end{array}$ & $\begin{array}{l}\text { Persentase } \\
\text { tingkat } \\
\text { kesalahan } \\
\text { pelaporan } \\
\text { permasalan di } \\
\text { setiap lokasi } \\
\text { berkurang } \\
\text { dikarenakan } \\
\text { data/ } \\
\text { dokumen/ } \\
\text { laporan } \\
\text { dikirimkan } \\
\text { sesuai dengan } \\
\text { lokasi petugas } \\
\text { lapangan }\end{array}$ \\
\hline
\end{tabular}

\section{G. Fase Migration Planning}

Pada fase migration planning ini, akan dilakukan perhitungan dan pertimbangan untuk dilakukannya transisi arsitektur, disertai dengan rencana implementasi dan rencana migrasi. Pada tahap ini akan dilakukan penganalisisan value dan risk yang akan dihasilkan oleh penerapan dan pengembangan proyek TI pada fungsi produksi tanaman pangan dan hortikultura. Proses ini dilakukan menggunakan metode analisis kuisioner yang diisikan oleh pihak Distan Provinsi Jawa Barat. Rentang nilai yang terdapat pada kuisioner ini adalah sebagai berikut:

1. Value/ Risk $1=$ Very Low

2. Value/Risk $2=$ Low

3. Value/Risk $3=$ Medium

4. Value/Risk $4=$ High

5. Value/ Risk $5=$ Very High 
Tabel XII menggambarkan hasil penilaian value dan risk terhadap proyek aplikasi dan infrastruktur oleh pihak Distan Provinsi Jawa Barat.

TABEL XII

APPLICATION PORTFOLIO CATALOG

\begin{tabular}{|c|l|c|c|}
\hline No. & \multicolumn{1}{|c|}{ Proyek } & Value & Risk \\
\hline 1. & Aplikasi E-Registration & 3 & 6 \\
\hline 2. & Aplikasi E-Tracking & 4 & 6 \\
\hline 3. & Aplikasi Location Report & 2 & 5 \\
\hline 4. & Aplikasi DMS Produksi & 4 & 7 \\
\hline 5. & Infrastruktur File Server & 4 & 6 \\
\hline 6. & Infrastruktur Mail Server & 2 & 4 \\
\hline 7. & $\begin{array}{l}\text { Infrastruktur Web Server dan } \\
\text { Database Server }\end{array}$ & 4 & 5 \\
\hline 9. & Infrastruktur Data Warehouse & 4 & 7 \\
\hline
\end{tabular}

Dari hasil analisis pertimbangan value dan risk, maka akan digambarkan pemetaan business value assessment diagram yang menggambarkan proyek-proyek TI berdasarkan analisis value dan risk yang telah dilakukan.

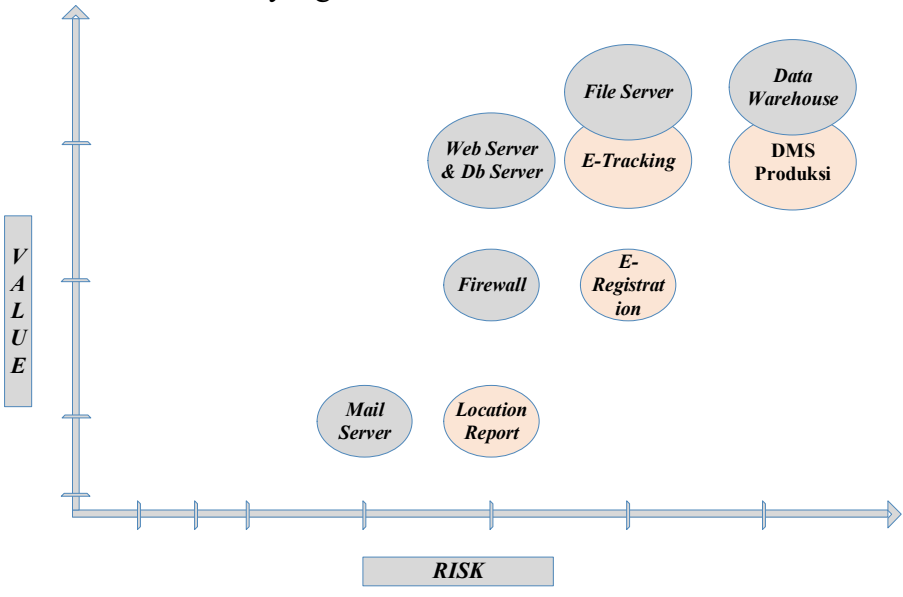

Gambar 2 Businee Value Assessment

Pada Gambar 2 merupakan business value assessment diagram untuk fungsi produksi tanaman pangan dan hortikultura yang berdasarkan hasil penilaian kuisioner oleh Distan Provinsi Jawa Barat. Business value assessment diagram memperlihatkan seberapa besar proyek TI, nilai value yang dimiliki, serta nilai risk yang akan dirasakan dari pengembangan proyek tersebut. Gambar 2 merupakan diagram business value assessment untuk fungsi produksi tanaman pangan dan hortikultura yang berdasarkan hasil penilaian kuisioner oleh Distan Provinsi Jawa Barat.

Langkah terakhir dari perancangan migration planning, yaitu melakukan penganalisisan terhadap architecture roadmap yang ditentukan oleh hasil penilaian value dan risk, dan dengan pertimbangan lainnya. Tabel XIII merupakan penggambaran architecture roadmap pada fungsi produksi tanaman pangan dan hortikultura Distan Provinsi Jawa Barat.

TABEL XIII

ARXHITECTURE ROADMAP

\begin{tabular}{|c|c|c|c|c|c|}
\hline \multicolumn{6}{|c|}{ High Level Roadmap } \\
\hline & 2018 & 2019 & 2020 & 2021 & 2022 \\
\hline \multicolumn{6}{|l|}{ Infrastructure } \\
\hline \multicolumn{6}{|l|}{ Web Server dan } \\
\hline \multicolumn{6}{|l|}{ Database } \\
\hline \multicolumn{6}{|l|}{ Server } \\
\hline \multicolumn{6}{|l|}{ Data } \\
\hline \multicolumn{6}{|l|}{ Warehouse } \\
\hline \multicolumn{6}{|l|}{ File Server } \\
\hline \multicolumn{6}{|l|}{ Mail Server } \\
\hline \multicolumn{6}{|l|}{ Firewall } \\
\hline \multicolumn{6}{|l|}{$\begin{array}{l}\text { Information } \\
\text { Systems }\end{array}$} \\
\hline \multicolumn{6}{|l|}{ DMS Produksi } \\
\hline \multicolumn{6}{|l|}{ E-Tracking } \\
\hline \multicolumn{6}{|l|}{ E-Registration } \\
\hline Location Report & & & & & \\
\hline
\end{tabular}

\section{KESIMPULAN}

Pada penelitian ini dilakukan pengidentifikasian untuk menghasilkan suatu rancangan enterprise architecture existing dan target pada fungsi produksi tanaman pangan dan hortikultura dengan menggunakan metode perancangan TOGAF ADM. Rancangan enterprise architecture akan digunakan sebagai guidline atau pedoman dalam penerapan dan pengembangan TI pada instansi dengan menyesuaikan dengan kebutuhan bisnis Distan Provinsi Jawa Barat. Dengan adanya enterprise architecture, maka akan memberikan solusi bagi permasalahan yang ada, sehingga instansi dapat menjamin keberlangsungan bisnisnya. Hasil atau output dari penelitian ini salah satunya yaitu berupa perancangan roadmap TI yang digunakan sebagai rekomendasi dari pengembangan dan implementasi TI dalam kurun waktu tertentu. Roadmap ini dapat membantu instansi dalam menentukan prioritas pelaksanaan proyek TI yang telah dirumuskan pada arsitektur target.

Perancangan arsitektur yang telah dibuat tidak akan dapat terimplementasi dan berjalan dengan baik apabila tidak ada pihak instansi yang mengerti dan memahami konsep enterprise architecture, maka dari itu dibutuhkan pihak yang mengerti dan dapat mengimplementasikan juga mengembangkan enterprise architecture yang akan diterapkan pada Distan Provinsi Jawa Barat. Berdasarkan penelitian yang telah dilakukan ini, terdapat kekurangan dalam penyelesaian perancangan EA, dimana penelitian ini hanya dilakukan hingga fase Migration Planning. Alangkah lebih baiknya jika dalam penelitian selanjutnya yang sejenis, dapat dilakukan hingga fase Architecture Change Management pada TOGAF ADM yang merupakan fase akhir dari perancangan EA. 


\section{DAFTAR PUSTAKA}

[1] The Open Group. (2011). ADM Overview TOGAF 9.1. The Open Group

[2] Kurniawan, N. B. (2013). Enterprise Architecture Design for Ensuring Strategic Business IT Alignment (Integrating SAMM with TOGAF 9.1).

[3] Mindrayasa, I., Murahartawaty, M., \& Hanafi, R. (2015). Analisis dan Perancangan Data Architecture dan Application Architecture Menggunakan The Open Group Architecture Framework Architecture Development Method (TOGAF ADM) Pada PT Shafco Multi Trading. Jurnal Rekayasa Sistem \& Industri (JRSI), 2(03), 67-74.

[4] Putra, G. M., \& Syukur, A. (2013). Pemodelan Arsitektur Enterprise untuk Mendukung Sistem Informasi Terintegrasi Menggunakan Enterprise Architecture Planning di SMP RSBI Negeri 7 Tegal. Teknologi Informasi, 22-39.

[5] Yunis, R., \& Theodora. (2012). Penerapan Enterprise Architecture Framework untuk Pemodelan Sistem Informasi.

[6] Setiawan, R. (2015). Perancangan Arsitektur Enterprise Untuk Perguruan Tinggi Swasta Menggunakan TOGAF ADM. Jurnal Algoritma Sekolah Tinggi Teknologi Garut.

[7] Karunia, I. P. (2015). Perancangan Enterprise Architecture Menggunakan TOGAF Architecture Development Method (Studi Kasus: Dinas Tata Kota, Bangunan dan Permukiman Kota Tanggerang Selatan).

[8] Utomo, A. P. (2014). Pemodelan Arsitektur Enterprise Sistem Informasi Akademik pada Perguruan Tinggi Menggunakan Enterprise Architecture Planning. SIMETRIS, 33-40.

[9] Anfusa Gandri Herucakra, A. F. (2015). Analisis dan Perancangan Enterprise Architecture untuk Mendukung Fungsi Terkait System Online Payment Point Menggunakan Framework TOGAF ADM pada PT Pos Indonesia.

[10]Shafa, A., Prasetyo, Y.A. and Mulyana, R., Analysis and Design Enterprise Architecture of Development Analysis Business Function at Badan Perencanaan dan Pembangunan Daerah (BAPPEDA) West Java Province Using TOGAF ADM Framework. 